\title{
6. Regenerating governance on Kaanju homelands
}

\section{Benjamin Richard Smith}

\section{Introduction}

Across Australia, the complexities of Indigenous governance are increasingly recognised. These complexities are apparent in intercultural engagements between Aboriginal people and the Australian 'mainstream', but they are also a feature of what is often described as the 'Aboriginal domain'. This chapter explores governance in central Cape York Peninsula-focusing on the upper watersheds of the Wenlock and Pascoe Rivers - where these two sets of complexities are deeply interwoven and are now manifest as aspects of a single, heterogeneous field of governance.

Kaanju people, who consider the upper Wenlock and Pascoe Rivers to be their traditional country, have recently sought to reestablish their presence there through the development of 'outstations' or 'homelands'. These outstations are small kin-based communities whose populations continue to move between homeland camps and larger communities, including the township of Coen (Smith 2004). Kaanju people have also regained some measure of control of their homelands through land claims and through the development of organisations concerned with the environmental and economic management of their 'country'. These organisations are the basis of Kaanju people's attempts to develop sustainable futures, by facilitating their involvement in political processes and through generating economic benefits from homelands-based projects. Given the growing number of projects currently based in Kaanju homelands - many of which include a potentially significant economic component-these organisations have, not surprisingly, become the subject of increasing contestation among the Aboriginal people involved with them.

In addition to contestation over governance arrangements between local Aboriginal people, the contemporary field of governance has also been shaped by a number of non-Indigenous or 'outside' organisations. These include various State and Federal government agencies and a series of non government organisations (NGOs) concerned with Aboriginal socioeconomic development and natural resource management. These organisations - and key individuals working within them - have responded to the reoccupation of Kaanju homelands by supporting homelands-based development. Development projects have been supported in a manner intended to lead to a rapprochement between the aspirations of various Kaanju people and what those working in these 
organisations regard as viable or sustainable forms of Indigenous social and economic development.

The resulting interplay between various local and 'outside' interests has produced a field of governance marked by ongoing tensions. In particular, there are tensions between Aboriginal aspirations for what might broadly be described as 'self-determination' and forms of support that remain conditional on working within frameworks determined by local and regional organisations and by government agencies. The resulting tensions focus on three key areas of contestation:

- the relationship between homelands-based, sub-regional and regional 'Aboriginal organisations' (as well as between these organisations and government agencies)

- the relationship (both putative and enacted) between contemporary forms of Aboriginal law and custom ('Indigenous governance') and 'mainstream' forms of governance and government, and

- the relationship between different forms of Aboriginal identity - in particular in the articulation of Aboriginal groups of various kinds at various social scales.

Whilst the first of these sets of relationships (between various formally-constituted organisations) involves relatively discrete kinds of social institution, careful examination of the various relationships constitutive of Indigenous community governance suggests that Aboriginal and 'mainstream' aspects of governance are now deeply interwoven in a single-albeit complex-field. This is the case despite continuing Aboriginal and non-Indigenous claims to the contrary. Further, despite marked continuities from pre-colonial Aboriginal sociality, it seems that contemporary articulations of Kaanju identities and interests at various scales are now deeply embedded within this contemporary field of governance. In the contemporary region, Aboriginal identities, as well as the field of governance and its constituent institutions and practices, are now markedly intercultural.

\section{The Aboriginal domain, the mainstream and the intercultural field}

A number of anthropologists have recently emphasised the intercultural character of Aboriginal life-worlds across northern and central Australia (see Hinkson and Smith 2005a). The empirical and theoretical accounts presented by these scholars move away both from a previous anthropological distinction between an 'Aboriginal domain' and a (socially if not culturally dominant) Australian 'mainstream'. This parallels the distinction prevalent in the popular imagination between the life-worlds of Aboriginal people living in very remote areas and 
the norms, values and practices that predominate elsewhere in Australian life - a distinction that underlies much Indigenous policy.

Such a distinction-also commonly made by many Aboriginal people themselves - has found more nuanced expression in various anthropological accounts of the 'Aboriginal domain'. This domain is understood to exist variously as a space in which social closure acts as a form of Aboriginal resistance to non-Indigenous dominance (e.g. Trigger 1986, 1992) or a set of practices (von Sturmer 1984) in which:

the dominant social life or culture is Aboriginal, where the system of knowledge is Aboriginal, where the major language is Aboriginal; in short where the resident Aboriginal population constitutes the public (von Sturmer 1984: 219).

Both in these anthropological accounts, and (often with less nuance) in popular understandings and the 'administrative imagination' (cf. Rowse 1992), this Aboriginal domain, space or life-world is contrasted to a putative 'mainstream', broadly taken to indicate the commensurate dominance of social life and cultural production $^{1}$ by 'white', 'European', 'Anglo-Celtic', 'modern' or 'Australian' forms of knowledge, language ('Standard English') and a predominantly non-Indigenous public. ${ }^{2}$

Conceptualising a distinct Aboriginal domain differentiated from this 'mainstream' has proved useful in treating ethnographic accounts of social interactions and hegemonic relations in remote majority Aboriginal settlements. In his discussion of Aboriginal governance, for example, Keen (1989: 21) notes the usefulness of 'treating the Aboriginal domain as a conceptual isolate ... distinguishing it from its [wider social and political] environment'. But the increasing interpenetration of Aboriginal and 'mainstream' life-worlds in places like central Cape York Peninsula means that this kind of treatment now provides only a partial account of the character of Aboriginal governance.

For this reason, when writing about the central Peninsula I have reservations in treating 'Indigenous Community Governance' in terms of a central core of informal and formal aspects of Aboriginal governance, located within a surrounding 'governance environment' (Hunt and Smith 2006a: 39-42; and compare Keen, passim). Rather, whilst there are spaces, spheres of thought and styles of behaviour (Trigger 1986: 99) in the central Peninsula that are readily identifiable as constitutive of an 'Aboriginal domain', a more even-handed

\footnotetext{
1 I follow Merlan's $(1998,2005)$ use of the term 'cultural production' to indicate the continuing reproduction and recreation of cultural categories, understandings and modes of practical action within day-to-day social life.

2 Although beyond the scope of the present paper, this discussion could usefully engage with the recent development of anthropological consideration of the nature of 'publics' and 'public culture'.
} 
analysis of governance - in its fullest sense - must account for these as moments within a broader social field.

The concept of the social field has a relatively long history in social anthropology. It is perhaps most closely associated with the work of Max Gluckman and the 'Manchester School' (e.g. Gluckman 1968), whose work included accounts of interethnic relations in the context of governance in sub-Saharan Africa. More recently, the term has been taken up by anthropologists working in Aboriginal Australia (e.g. Smith 2007; Sullivan 2005).

Following Gluckman, it is possible to understand events and institutions associated with a particular 'domain' as part of a wider social field. Such an understanding entails the analysis of:

[a] set of social institutions ... and their 'intermesh' [in which] ... [e]vents emerging from the operation of one institution may intervene in the operation of another institution in a manner that is haphazard as far as the systematic interdependencies of the recipient institution are concerned. [Further,] [e]xternal events from quite different areas ... may intrude into the field under analysis, again in what, from the point of view ... of systems, is a haphazard manner (Gluckman 1968: 223).

Nonetheless, more careful examination of such events and interactions may well reveal:

that institutions and wider social fields have a marked tendency to endure, that they and/or their parts are resistant to both unintended and deliberately attempted changes, though radical changes will, after some period of time, occur. We might therefore say that an institutional system, or a field of institutional systems, will tend to develop, and even hypertrophy, along the main facets of its organisation, until conditions make it quite impossible for the system to continue to work (ibid.).

In the analysis that follows, I take up Gluckman's model of a social field in relation to Indigenous community governance as it has developed in the central Peninsula, but with some qualifications.

My first qualification is that Gluckman's use of the term 'institution' should be read here as inclusive both of formal and informal social institutions and of instituted forms of behaviour, knowledge and the like; in what follows, I understand 'institutions of governance' to form parts of a socio-cultural field. Secondly, I understand Gluckman's use of the term 'haphazard' to indicate, on one hand, the relatively open trajectories of socio-cultural production in fields marked by the interplay of originally distinct (Aboriginal and settler) socio-cultural forms. On the other hand, the term 'haphazard' also marks the unexpected results of interventions by those within this shared field. In particular, I am thinking of the interventions of non-Indigenous agencies, the 
'haphazard' results of which often seem unpredictable to those working within these agencies. Lastly, I am reticent to discuss the endurance of those 'institutions' that together mark the 'Aboriginal domain' in terms of their 'parts'. Notions of 'parts and wholes' as they are often applied to Aboriginal socio-cultural production are extremely problematic (cf. Strathern 1992). Indeed, the imposition of notions of parts and wholes marks one of the principal ways in which non-Indigenous socio-cultural production forces radical changes within the field of Indigenous community governance, such that it is near impossible for aspects of the Aboriginal domain to persist within this wider field.

This last point concerns a key problem within the wider field of Indigenous governance in the central Peninsula - the contrasting (and culturally-shaped) expectations and enactments of leadership in relation to governance arrangements involving wider sets (or 'groups') of Aboriginal people. Again, I am reticent to use the language of 'groups' here because - as Keen (1989) insightfully argues - although 'leadership' is clearly identifiable within those parts of the field of governance that we might identify as the 'Aboriginal domain', within that domain, leadership does not operate in relation to a social structure of pre-given 'groups'. Instead, such leadership is linked to a more fluid or processual articulation of 'social networks and fields' (Keen 1989: 26). However, in recent years it has become increasingly apparent that, despite their incommensurability, originally exogenous ('outside') understandings of Aboriginal social life (ideas about 'tribal groups' for example) have folded back onto Aboriginal people's own reckonings of sociality and governance within the region's shared social field. The result is commonly what Gluckman (1968: 223) describes as the haphazard outcome of the intervention of one institution 'in the operation of another institution ... as far as the systematic interdependencies of the recipient institution are concerned'. Put more simply, the folding back of such reckonings of sociality into local usage leads to a problematic-and often antagonistic - articulation of the socio-cultural modes of the Aboriginal domain and those introduced from the 'mainstream' within the shared field of governance.

The manner in which these differing conceptualisations of leadership, social networks, groups and the like come to affect each other indicates the cultural complexities of the contemporary field of governance. The ongoing interplay of originally distinct Aboriginal and settler socio-cultural forms has led to this field now possessing a profoundly intercultural character. Whilst the character of this field remains heterogeneous, the intermesh of its various social and cultural 'institutions' is such that even seemingly autonomous aspects of Aboriginal cultural production are, in fact, deeply shaped by their exposure to aspects of 
the 'mainstream'. ${ }^{3}$ For this reason, the field of governance is intercultural in the sense that this term is used by Merlan (2005). ${ }^{4}$ That is, the various 'institutions' and forms of thought, action and personhood which together constitute this field are deeply interwoven, but are by no means heterogeneous. Rather, the interweaving or 'mutual exposure' (Smith 2007) through which this field is constituted is marked by ongoing forms of socio-cultural difference, similarity, and mutual engagement and transformation. And, as Gluckman's earlier analysis of social fields suggests, such intercultural fields are marked by ongoing changes, reconfigurations and realignments.

In order to better understand how such an intercultural field has developed, its contemporary complexities, and the changes that continue to be enacted within it, I now turn to relationships of governance within a particular area of the central Peninsula - the homelands of the Kaanju people of the upper Wenlock and Pascoe rivers. More particularly, what follows focuses on the history of decentralisation - the reoccupation of homelands or 'outstations' - and the forms of governance that developed in relation to this 'outstation movement'.

\section{Kaanju homelands}

Kaanju homelands $(\text { ngaachi })^{5}$ stretch from the township of Coen in the centre of Cape York Peninsula to around the former Moreton Telegraph Station to the north (Fig. 6.1), covering the headwaters of the eastern and western-flowing river systems that run off the Great Dividing Range. The Aboriginal people of this area spoke and owned ${ }^{6}$ the Kaanju language, which they considered to have been emplaced in their 'country' through the actions of mythological, ancestral hero figures (called 'Stories' in the region's Aboriginal English). However, neither this area, nor the Kaanju-speaking people who owned and occupied it, were considered as a homogenous group. Rather, particular Kaanju people identified with places and areas within the wider Kaanju bloc, and exercised particular rights with regard to such places on the basis of these identities. These identities were in turn based upon the actions of the 'Stories', which shaped or left various

\footnotetext{
${ }^{3}$ Likewise, despite the continuation of hegemonic relationships between local Aborigines and 'outside' agencies, the local operations of these agencies are inexorably shaped by their involvement with particular Aboriginal people. Not least because, as Scott (1998) insightfully argues, the operations of state (and state-like) agencies depends on the enactment of otherwise lifeless schema in particular local life-worlds.

4 For other accounts of the 'intercultural' in Aboriginal Australia, see Martin (2003); Smith (2007); Hinkson and Smith (2005b); Sullivan (2005).

${ }^{5}$ I use italics throughout this chapter to denote words from the Kaanju language and other Indigenous language varieties (except for proper names, which are not italicised). Words and phrases in the region's Aboriginal English are not italicised, but are placed in inverted commas.

6 Aboriginal language varieties in the central Peninsula are understood to be substantially connected to land or 'country' through the actions of mythological beings ('Stories'). These languages are further understood to be jointly owned by all those whose country is connected to a particular language in this manner (see Rigsby 1999; see also Merlan 1981; Rumsey 1989). This is despite the previous lack of any formal social organisation at the (language-named) 'tribal' level.
} 
named 'Story-places' across the regional landscape. Several such places - along with other named sites - were considered the joint property of sets of close kin. Anthropologists often identify these sets of people as 'clans', but they were locally identified by the use of the suffix - thampanyu ('associated with' - see Thomson 1933; Chase 1980) attached to the name of a place, an associated totem, or another signifier of conjoint place-based identity. These-thampanyu identities formed the basis of a regional system of property rights. They were also closely tied to other aspects of regional Aboriginal governance, which was enacted primarily between sets of senior men from across the region.

This regional system of land-ownership and governance - and the associated use of Kaanju 'country' by hunter-gatherer bands - was disrupted by the arrival of white settlers in the central Peninsula in the late $19^{\text {th }}$ century. Following the discovery of gold at several locations in the wider region, miners flooded into the central Peninsula, followed by pastoralists who took up large cattle runs to supply the miners and the townships that they established. Kaanju people experienced considerable social and cultural impacts following the establishment of the township of Coen - at the southern limit of Kaanju country - and the mining fields and camps near Birthday Mountain and on the upper Wenlock River (then called the Batavia River), which were also established on their homelands (Fig. 6.1). In addition, a number of cattle stations - including Mt. Croll, Pine Tree, Rokeby, Merluna and Batavia Downs - were established on Kaanju homelands, with the majority of Kaanju country being taken over for the running of cattle. Displaced from their hunting grounds and subject to disease, malnutrition and settler violence, Kaanju people were forced to live in fringe camps close to the major centres of white settlement, or to move to the mission stations on the land of their coastal neighbours at Lockhart River, Weipa and Mapoon. As the cattle industry grew, increasing numbers of Kaanju people worked on cattle stations on their own homelands or in other parts of the Peninsula. Significant numbers of Kaanju people - including a number of mixed-race children - were also removed ${ }^{7}$ to the missions and penal settlements at Cherbourg, Woorabinda, Yarrabah and Palm Island. Those so removed (and their descendants) have subsequently formed part of the Peninsula's Aboriginal diaspora or 'stolen generations' (Smith 2000a, 2006).

\footnotetext{
${ }^{7}$ Under the regime of state control legislated for by the Queensland Government's Aboriginals Protection and Restriction of the Sale of Opium Act 1897 and subsequent legislation.
} 
Fig. 6.1 Central Cape York Peninsula outstations map

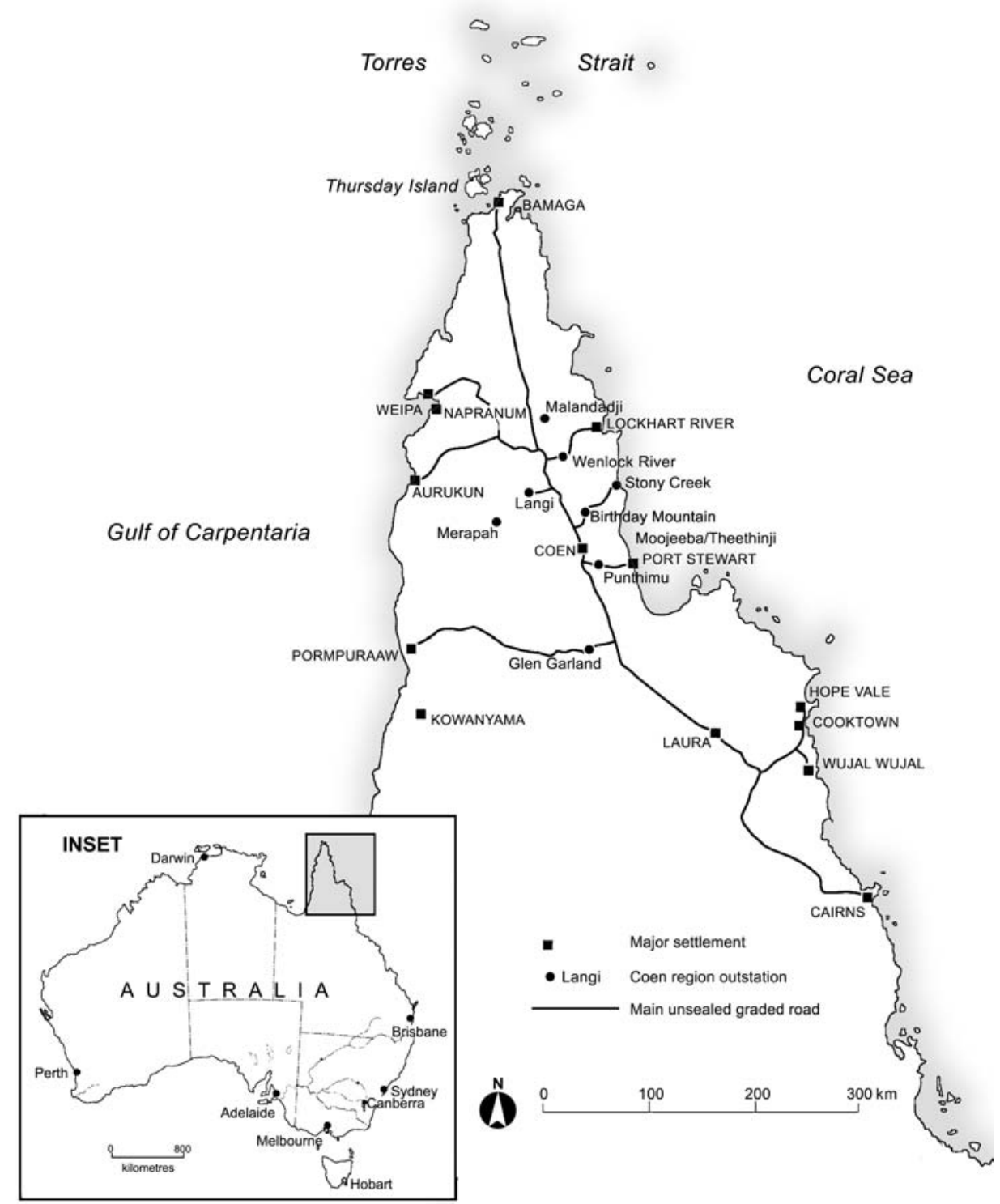

In the late 1960s and early 1970s, a decline in pastoral employment was exacerbated by the recognition of Aboriginal citizenship and the granting of award wages. As a result, Kaanju people living in the central Peninsula found themselves centralised in places like Coen, a small township in the centre of the Peninsula, as well as at discrete Aboriginal settlements like Lockhart River and other former mission or government settlements. This situation persisted until the late 1980s, when the establishment of a series of Aboriginal corporations in 
Coen, and the increasing possibility of access to traditional land through claim, transfer and purchase processes, allowed Kaanju people to re-establish permanent living spaces on their country.

\section{Kaanju outstations (1989-96)}

In the late 1980s and early 1990s, two distinct groups of Kaanju people sought to establish 'outstations' on their homelands, and to regain control of their country through land claims. The first of these groups was centred on an extended family ${ }^{8}$ whose forebears' clan country lay just to the north of Coen, around Birthday Mountain (Watharra). ${ }^{9}$ The second group, which included a number of closely related members of several extended families, sought to re-occupy country on the upper Wenlock River.

For this latter group, the desire to return to country was complicated by the character of mainstream land tenure on their homelands. The principal 'boss' of this group in the 1980s, M_, a Kaanju woman then in her forties, had a particular connection to a stretch of the Wenlock River focused on the Lightning Story-Place, Malantachi. However, this Story-Place, along with much of M_'s father's country (with which she primarily identified), was occupied by an 'experimental farm' run by Queensland's Department of Primary Industries. ${ }^{10}$ The only available land for the establishment of an outstation lay further upstream, close to the Frill-Neck Lizard Story-Place called Chuulangun (Dusty Lagoon), on the upper Wenlock River just inside the Deed of Grant in Trust (DOGIT) lands of the Lockhart River Aboriginal community.

In order to establish the Wenlock River outstation, $M_{-}$needed the support of other Kaanju people with closer ties to the country around Chuulangun. In part, this support was needed to gain the formal permission of Lockhart River Council to establish the outstation within the DOGIT. But M_'s primary consideration appears to have been the 'informal' permission she required, in accordance with local Aboriginal Law, to undertake the establishment of an outstation on an area somewhat removed from her father's principal country. To this end, she sought the support of two senior Kaanju men, T_ (her cousin) and S_ (her classificatory uncle). Both of these men had close connections in the vicinity of Chuulangun. T_'s principal ties were to the nearby Eagle-Hawk Story-Place called Nantanchi, and S_'s connections centred on the 'Tommy-Round Head Lizard' Story-Place at Mula at the headwaters of the Pascoe River. In partnership with these two senior Kaanju men, $M_{-}$was able to develop the Wenlock River outstation with funds administered by an Aboriginal corporation in Coen, whilst simultaneously

\footnotetext{
8 Here, and throughout this paper, my use of the term 'family' indicates what Sutton (2003: 206-9), following the common Aboriginal use of the term 'family', identifies as 'families of polity'.

${ }^{9}$ See, Land Tribunal 1995.

${ }^{10}$ This farm had previously been a pastoral lease, which was the subject of compulsory purchase by the Queensland Government.
} 
seeking support for regaining control of her own country around Malantachi, where she also hoped to establish a camp.

At this early stage in the development of the outstation, the complex interplay between 'informal' aspects of governance within the Aboriginal domain and 'formal' Aboriginal organisations and councils was already apparent. On the one hand, M_'s establishment of the outstation at Chuulangun depended upon a negotiation of particular interests in Kaanju country distributed among a set of senior men and women (including $T_{-}$and $S_{-}$, as well as $M_{-}$herself). These more localised interests together coalesced into a wider 'countryman' (Chase 1980) grouping of Kaanju people from the upper Wenlock and Pascoe river systems, who jointly re-established and utilised the Wenlock outstation camp.

But these localised and countryman identities - key aspects of governance within the Aboriginal domain - articulated with more formal aspects of the region's field of governance. These more formal aspects of governance included the Lockhart River Aboriginal Shire Council, whose permission was needed to allow the establishment of the outstation on the DOGIT. They also included several Aboriginal corporations based in Coen, ${ }^{11}$ where $M_{-}$and $T_{-}$both lived.

Importantly, the manner in which Kaanju governance was articulated in the formal governance arrangements at Coen and Lockhart River varied both in scale and style from the manner in which Kaanju governance was enacted within the Aboriginal domain. In Coen, for example, Kaanju people were formally represented as members of two discrete groups - the 'Northern Kaanju' (who included M_ and the other Kaanju people from the Wenlock and Pascoe rivers) and the 'Southern Kaanju', a term taken to identify Kaanju people from the more southerly Archer River system, but which in practice was near-synonymous with the Coen-based Kaanju family from Watharra (Birthday Mountain).

The principal cause of the emergence of this formal 'Northern' and 'Southern Kaanju' distinction seems to have been the development of a land claim (under Queensland's Aboriginal Land Act 1991) over the Birthday Mountain area. In developing this claim, $\mathrm{C}_{-}$, the senior member of the Wathara-associated family group, sought to limit the claimant group to his own 'clan' or 'family'. As the claim process developed, however, the claimant group was broadened to include all 'Southern Kaanju' families. But the claim continued to exclude the 'Northern Kaanju' group, an exclusion based on linguistic and social distinctions between Kaanju people from the Archer River and the Wenlock and Pascoe river areas.

Sutton (1996) has outlined the expansion of the Birthday Mountain claimant group, an event whose concern with social scale in relation to traditional

\footnotetext{
11 These included the Moomba and Malpa Kincha corporations, established in the late 1980s, and their successor, the Coen Regional Aboriginal Corporation, established in 1993 (see Smith 2000b).
} 
ownership is of relevance to understanding the field of governance in the central Peninsula:

It is sometimes the case that people maintain proximate entitlements to small areas such as classical [clan] estates as well as an identification with more widely cast landed entities such as language groups ... Such a situation may lead to conflict. In the Birthday Mountain land claim ... this particular distinction came to a head when the claim was lodged solely on behalf of a small descent group ... Other southern Kaanju people lodged a subsequent claim over the same land ... [Later] the two sets of claimants came to a signed settlement to the effect that ... the southern Kaanju as a whole had traditional affiliation to the claimed land [but] the small descent group were the owners of the land under Aboriginal tradition ... Here was a case in which an assertion of autonomy by a group holding proximate title failed, not completely, but partially, and as a result of the assertion of interests by those speaking for a wider group that included them (Sutton 1996: 24).

Comparable forms of contestation by 'groups' of various scales has occurred in relation to 'Northern Kaanju' country, although - as I argue below - the language of 'groups' may not be the best way to apprehend the articulation of differing interests in such cases.

At the same time that the 'Southern Kaanju' group was engaged in the Birthday Mountain land claim, the newly formed Coen Regional Aboriginal Corporation (CRAC) reserved places for 'Northern Kaanju' and 'Southern Kaanju' representatives on its Board of Directors, alongside representatives of several other Coen-based 'tribes' and a set of people whose primary identity was as a 'town mob' (Smith 2000b). But despite the obvious attempt by CRAC to produce a 'culturally appropriate' form of representation - by way of reserved places for the region's various 'tribal' factions - there was a clear difference apparent between the notion of representation that underlay the development of the CRAC board (that a senior man or woman could speak for an amalgamated 'tribal' group) and the carefully negotiated politics of 'speaking for country' apparent between $M_{-}$and other senior Kaanju people. Further, the reified 'Northern' and 'Southern Kaanju' 'tribal' groups-presumed by CRAC to exist as principal sociopolitical conglomerations within regional Aboriginal governance-were also at odds with a more localised emphasis on country within the region's Aboriginal domain. Nonetheless, rather than a distinction between 'Aboriginal' and 'formal' governance arrangements, the late 1980s and early 1990s instead saw ongoing attempts at an accommodation between informal Aboriginal values 
and processes, and formal representation within CRAC. ${ }^{12}$ In this way, reified constructs like the 'Northern Kaanju' identity acted as place-holders for M_and her relations' engagements with outsiders, whilst the flow of resources that enabled the development of the Wenlock River outstation reinforced the reproduction of a conjoint 'countryman' group of Kaanju people with shared interests in the Wenlock River outstation and surrounding areas of Kaanju country.

\section{Development of Chuulangun (late 1990s-present)}

A number of changes occurred in the regional field of governance in the late 1990s. These included changes in the Kaanju people acting as the focal men and women for 'business' involving homelands on the upper Wenlock and Pascoe rivers, and a growing set of organisations becoming involved in the governance of these homelands.

\section{Fig. 6.2 Kinship relations of the Wenlock outstation 'mob'}

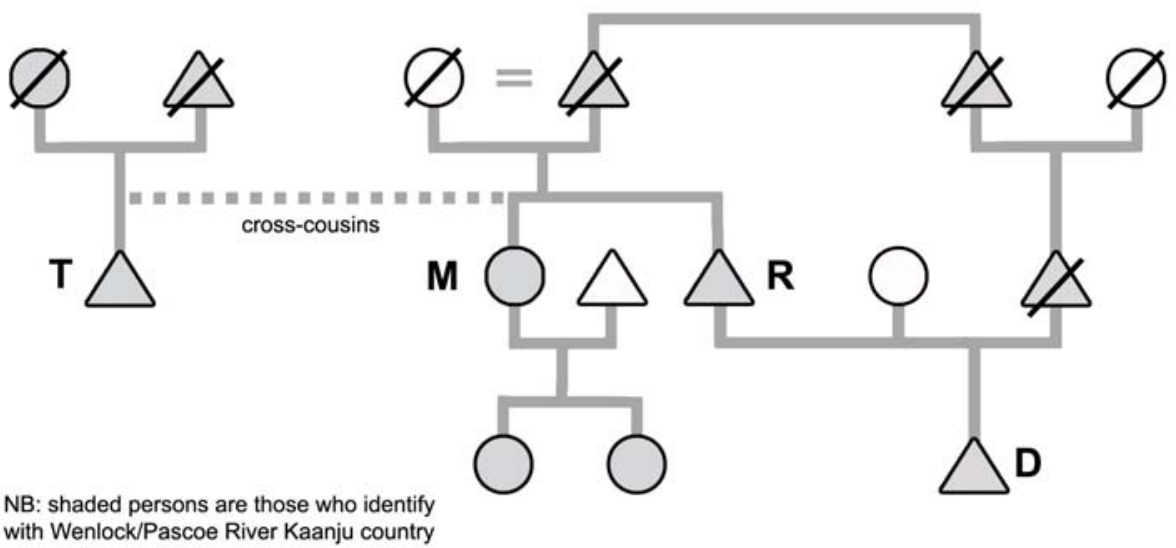

In the mid 1990s, the set of men and women primarily involved in Aboriginal decision making for Kaanju homelands on the upper Wenlock and Pascoe rivers changed following the death of $S_{-}$and the increasing involvement of $M_{-}$'s brother $\mathrm{R}_{-}$, who had returned to the central Peninsula in the intervening years (see Fig. 6.2). $\mathrm{R}_{-}$and his wife $\mathrm{V}_{-}$had taken up residence at the Wenlock River outstation, and took primary responsibility for the day-to-day running of the camp, which had become the focus of $\mathrm{R}_{-}$'s intention to develop a cattle property on Kaanju land. T_ continued to move between the outstation and Coen, while $M_{\text {_ }}$ resided principally in Coen but maintained her position as the principal

\footnotetext{
12 Such formal representations were determined, in part, by the expectations and requirements of 'outsider' administrators, consultants and organisations, ranging from the first 'project manager' to regional Aboriginal and Torres Strait Islander Commission officers.
} 
'boss' for the outstation, in part due to $\mathrm{R}_{-}$'s disinclination towards taking such a role.

The Wenlock River camp had also attracted a number of other people as occasional residents, including the family of $A_{-}$, a senior Kaanju woman whose principal connections to country lay further upstream. A_'s family had become extremely influential at Lockhart River, where they usually resided, and had also become more involved with the outstation. A number of stolen generation Kaanju people had also begun to express increasing interest in 'business' pertaining to Kaanju homelands, although they lived in the settlements to the south of the Peninsula to which their forebears had been removed.

This shifting set of focal individuals was further shaped by the increasing prominence of $D_{-}, M_{-}$'s nephew, who began to move into a more active role in the late 1990s. Over time, D_ and his wife succeeded to control of the Wenlock outstation, whilst $\mathrm{R}_{\text {_ }}$ and $\mathrm{V}_{-}$( $\mathrm{D}_{-}$'s mother) shifted their principal place of residence to Coen. D_consolidated his focal role at the Wenlock camp following the deaths of $T_{-}$and $M_{-}$in the early 2000s.

As the new boss of the Wenlock camp, D_ moved to place what he understood to be 'proper Kaanju governance' at the heart of homelands' business. The crux of D_'s attempts to regenerate 'proper' Kaanju governance was his establishment of a formal structure - the Chuulangun Aboriginal Corporation (CAC). The corporation was based at the Wenlock River outstation, but purported to represent and to 'manage' a wide area of Kaanju land on the upper Wenlock and upper Pascoe rivers.

In part, $\mathrm{D}_{-}$sought to establish CAC in response to other governance arrangements, which he understood to be inappropriate. The CRAC, for instance, was seen as taking an improper 'sub-regional approach' to governance, instead of a form of governance 'from the inside out', based on homelands and directed by traditional owners living there. $\mathrm{D}_{-}$also established the CAC in reaction to an increasing 'regional' approach to governance, led by a series of organisations based in Cairns, as well as new governance arrangements based at Lockhart River.

The new Lockhart River arrangements were a source of considerable concern for $D_{-}$. Despite the ongoing focal role of Kaanju people living between Chuulangun and Coen, the outstation remained situated within lands managed from Lockhart River. The new Lockhart-based Mangkuma Land Trust (hereafter Mangkuma) - established following the 'handover' of the former Lockhart DOGIT to traditional owners (who include a number of coastal 'Sandbeach' people, as well as both 'Northern' and 'Southern Kaanju') — now vied with the more localised CAC for the control of the relevant part of the DOGIT. D_'s dissatisfaction with Mangkuma was further intensified by the appointment of a stolen generation man, $L_{-}$, as its chairperson. $L_{-}$asserted a Kaanju identity, 
and regarded himself as able to 'speak for' the country purportedly controlled by CAC. But L_'s understanding - and enactment - of Kaanju law and custom was at odds with D_'s. As a result, the conflict between the two men-and the formal bodies that they controlled - had also become a conflict over the definition of 'proper' governance within the Aboriginal domain. This conflict was exacerbated by D_'s parallel conflict with A_ and her family, which also focused on competing interpretations of Kaanju law and custom.

In this way, the conflicts over the appropriate forms of governance for Kaanju homelands involved disputes both over 'informal' governance, based in traditional law and custom and the 'Aboriginal domain', and competing claims between a series of organisations established at various scales of representation and with different mandates and styles of governance. But rather than being separate issues, these aspects of the field of governance were increasingly interwoven.

More recently, this interweaving of the Aboriginal domain and various local and regional Aboriginal organisations has been further intensified by a series of partnership arrangements between these organisations and a series of NGOs, researchers, and commercial operators. The resulting flow of resources for homelands-based projects has intensified the conflicts between the various factions, organisations and individuals involved. But alongside such conflicts, a series of crosscutting ties and partnerships between these organisations has also emerged. D_, for example, is currently a CRAC Director, despite his vocal criticisms of this corporation, and he has more recently become the Deputy Chairperson of Mangkuma (taking up the role following L_'s resignation as chairperson). $\mathrm{He}$ is also engaged with various Cairns-based 'regional' organisations, despite simultaneously seeking to lessen their influence on the governance of Kaanju country. More than ever, governance of Kaanju homelands is vested in a complex field of governance that simultaneously allows for conflict and competition, and for shifting partnerships and alliances.

\section{Discussion}

The field of governance in central Cape York Peninsula involves three sets of contested relationships that are constitutive of this field and its inherent complexities. Firstly, this field involves the articulation of homelands-based, 'sub-regional' and 'regional' Aboriginal organisations, in addition to the role played by State and Federal government agencies. Secondly, the region's field of governance involves both putative and enacted relationships between contemporary forms of traditional Aboriginal law and custom, and 'intercultural' and 'mainstream' governance processes. Lastly, the region's field of governance is marked by various forms of conjoint Aboriginal identity, articulated at different social scales. 
The relationship of homelands-based, 'sub-regional' and 'regional' Aboriginal organisations with one another, as well as their engagements with State and Federal government agencies, represents the first set of contested relationships constitutive of this field. The past two decades have seen the establishment of a range of such organisations, including a series of Aboriginal corporations in Coen and Mangkuma at Lockhart River, Cairns-based 'regional' organisations such as the Cape York Land Council and several homelands-based corporations like CAC. This proliferation of formally incorporated bodies recalls Sanders' (2004) suggestion that, rather than marking a 'failure' of Indigenous governance, the development of a complex and contested series of incorporated organisations meets particular socio-cultural and political requirements. The development of such representative structures may well mark a successful indigenisation of governance rather than a failure in the development of governance arrangements.

This recalls Gluckman's (1968: 223) suggestion, as mentioned above, that institutions and wider social fields have a tendency to endure, such that 'a field of institutional systems ... will tend to develop, and even hypertrophy, along the main facets of its organisation, until conditions make it quite impossible for the system to continue to work'. As Sanders suggests, a hypertrophic tendency - a tendency to enlarge and increase in complexity - is widespread in Indigenous community governance. The establishment of a range of organisations at different scales should not be regarded as accidental, but rather as an expression of the different ways in which both Aboriginal and non-Indigenous agents seek to enact governance.

Further, the fact that focal men and women like D_ dispute the operation of Indigenous governance at certain scales, whilst remaining involved with organisations operating at those scales, should not be taken simply as capitulation to pre-established conditions. Rather, the organisational structures, institutions and procedures of the central Peninsula's field of governance are themselves often partly driven by Indigenous relationships and systems (Hunt and Smith 2006a). This is one aspect of the increasing interweaving of formal and informal aspects of the regional field of governance. The resulting ability of Aboriginal people like D_ to activate formalised relationships of governance across various scales demonstrates the continuing existence of styles of Aboriginal politics within the contemporary field of governance surrounding Kaanju homelands.

Thus, as well as the interaction of formal Aboriginal organisations, the region's field of governance includes relationships between contemporary forms of traditional Aboriginal law and custom and formal structures and processes of governance. These relationships have been treated elsewhere in terms of 'cultural match' and 'legitimacy' (see e.g., Hunt and Smith 2006a).

Questions concerning 'cultural match' are important in relation to Kaanju homelands, not least because they are a focus of current disputes between various 
focal men and women and the organisations with which they are aligned. Here it is important to note the high degree of heterogeneity of the "preferred contemporary values, norms and conceptions of how authority should be organised and leadership exercised' (Hunt and Smith 2006b: 2). This heterogeneity implies that it may not be possible to discover a single governance arrangement best suited or most appropriate to this region. Rather, outside observers - and those entering into partnerships with Kaanju people in homelands-based projects - would do better to understand Aboriginal assertions about 'culture', 'law' and 'custom' as aspects of the shifting articulations of identity that remain deeply interwoven with Aboriginal politics. Likewise, issues of scale of representation or styles of decision making are deeply interwoven with the shifting field of relationality, autonomy and encompassment that lies at the heart of Aboriginal political life. To presume that there is a fundamentally legitimate cultural form or social scale that can be the basis of appropriate governance is to privilege one moment within the dynamic processes that constitute the regional field of governance.

For this reason, formal institutions of governance are deeply interwoven with less formal aspects of governance - in particular, the relational politics of the Aboriginal domain. This interrelationship problematises the idea of 'culture match'. In the central Peninsula, one cannot simply expect to 'match' an institution to an underlying social order. Rather, the various 'institutions' (whether formal or informal) that together constitute the field of governance are marked by ongoing processes of inter-relation and contestation. In generating a complex institutional field, local Aboriginal styles of governance have not been 'matched'. Rather, Aboriginal organisations have been accommodated within an existing field of governance, resulting in a hypertrophic series of organisations that extends the informal complexities of Aboriginal politics. ${ }^{13}$

The complexities of these local Aboriginal styles of governance include the articulation of various forms of Aboriginal identity at different social scales - particularly in relation to intra-Aboriginal politics. What Hunt and Smith (2006a: ix) call a 'continuum of localised and regionalised scales of population and land ownership' lies at the heart of the region's complex field of Indigenous governance. Here, rather than the 'groups' on which most attempts at formal Indigenous governance are based, what is apparent is the constantly shifting presentation of various conjoint identities as the basis of political action. As in the contested history of 'Southern Kaanju' people's involvement in the Birthday Mountain claim, 'Northern Kaanju' involvement in the governance of their homelands makes it clear that any attempt to identify a basic level or form

\footnotetext{
13 Conversely, the originally exogenous political formations and styles of the state have become intermeshed with local Aboriginal forms of governance, leading to the development of an intercultural field of governance.
} 
of Aboriginal governance obscures the inherent indeterminacy of the identities through which Aboriginal social and political life is enacted. Indeed, any such attempt at formalisation of Aboriginal 'groups' is likely to result in a reactionary projection of interests at a smaller or larger scale, again revealing the dynamic of 'autonomy and relatedness' (Martin 1993; Myers 1986) that lies at the heart of Aboriginal sociality. ${ }^{14}$

Issues of leadership and succession are similarly embedded in the negotiative, contested and fractious domain of Aboriginal political identities. Following the death of several of the region's focal men and women, succession in relation to Kaanju homelands 'business' was marked by the emergence of an intercultural representative politics, and by a move away from an emphasis on negotiative interrelation with an 'as of right' model of representation being asserted by at least one local 'leader'. But both of these phenomena were undercut by a continuing emphasis on a negotiative form of relational politics among Kaanju people. This negotiative character weakened the effectiveness of both CAC and Mangkuma, whilst those controlling these organisations avoided seeking widespread political support. L_'s recent resignation and D_'s concurrent move to engage a wider set of Aboriginal people in his projects suggest a realignment of both organisations towards the involvement of a wider range of 'countrymen'. This move may prove vital to these organisations in continuing to garner support from 'outside' organisations, support that remains essential to successful homelands development.

Despite their earlier shift away from the negotiative style of Aboriginal politics, both CAC and Mangkuma were previously managed to generate homelands-based development projects. But these projects were hampered by continuing inter-organisational and inter-personal conflicts, and by growing questions amongst the employees of partnering governmental and non-governmental organisations concerning the legitimacy of their operations. Whilst both organisations could claim some successes in relation to particular development projects on homelands, it seemed likely until recently that internal tensions and external caution might eventually have hindered the sustainability of such development.

The manner in which the relational style of Aboriginal politics has undermined organisations like CAC and Mangkuma recalls Hunt and Smith's (2006a) insistence that the governance environment can enable or disable. Certainly, it seems that where focal men and women exceed the support of their wider set of countrymen, the organisations for which they are responsible can face considerable difficulties.

\footnotetext{
14 Interestingly, all of the region's focal men and women-despite continuing disputes over the articulation of regional and local identities - recognise a wider level of regional connectedness. But exactly how this regional connectedness relates to Indigenous governance arrangements is a key aspect of the contested and cross-cutting articulation of politicised identity across the region.
} 
But I am not convinced that we can presume that such disabling effects are necessarily negative from local Aboriginal perspectives, even where they impede economic development. As anthropologists working with (former) hunter-gatherers have argued (see e.g., Woodburn 1982), these peoples - who commonly have a strongly acephalous political orientation-are often resistant to political formations that do not satisfy their interests, even where they will suffer material losses as a result. Although it is difficult to even consider such ideas within the current climate of Aboriginal affairs in Australia, it is vital to consider whether the disabling of governance arrangements may, on balance, be viewed as desirable by many Aboriginal people where these arrangements do not meet with their approval and support.

\section{Conclusion}

Rather than understanding Indigenous community governance in the central Peninsula in terms of incorporated organisations and an informal 'Aboriginal domain', both located within a wider 'governance environment', it can be best understood in terms of a complex regional field. Within this field, what Hunt and D. Smith (2006a: 76) have identified as 'four layers or dimensions of governance' - individual, entity, inter-relationships and 'environment' — can all be recognised. But disentangling these 'layers' in this manner involves the reification of aspects of a complex field, which can lead to both analytic and practical complications.

One important problem inherent in the notion of a surrounding governance environment is that it masks the substantial interweaving of the 'Aboriginal' and the 'mainstream', and the intercultural character of Indigenous community governance. This is analytically inaccurate - as the concept of the field of governance makes clear, 'outside' agencies and their interventions are very much a constitutive aspect of such fields. But any masking of this social, cultural and political interweaving also limits possibilities of an effective rapprochement between the various interests - Aboriginal and otherwise - at play in such fields.

\section{Acknowledgements}

This paper is based on research supported by the Australian Research Council, the Leverhulme Trust, the Australian Institute of Aboriginal and Torres Strait Islander Studies, the Emslie Hornimann Fund and the University of London. I am grateful to Kaanju people from the Wenlock and Pascoe rivers, and to the other families of central Cape York Peninsula, for their ongoing support of my research. I owe a particular debt to members of the Moreton/Nelson family, without whose ongoing support this paper could not have been written. I am also grateful to the two anonymous referees for their useful comments. Any errors of fact and analysis that remain are mine. 


\section{References}

Chase, A. 1980. Which Way Now? Tradition, Continuity and Change in a North Queensland Aboriginal Community, PhD Thesis, The University of Queensland, Brisbane.

Gluckman, M. 1968. 'The utility of the equilibrium model in the study of social change', American Anthropologist, 70 (2): 219-37.

Hinkson, M. and Smith, B. R. (eds) 2005a. Figuring the Intercultural in Aboriginal Australia, Special Issue, Oceania, 75 (3).

— and - 2005b. 'Introduction: conceptual moves towards an intercultural analysis', in M. Hinkson and B. R. Smith (eds), Figuring the Intercultural in Aboriginal Australia, Special Issue, Oceania, 75 (3): 157-66.

Hunt, J. and Smith, D. E. 2006a. 'Building Indigenous community governance in Australia: preliminary research findings', CAEPR Working Paper No. 31, CAEPR, ANU, Canberra.

— and - 2006b. 'Ten key messages from the preliminary findings of the Indigenous Community Governance Project, 2005', ICGP, CAEPR, ANU, Canberra, available at $<$ http://www.anu.edu.au/caepr/ICGP_ publications.php \#resreports $>$ [accessed 9 October 2007].

Keen, I. 1989. 'A boriginal governance', in J. C. Altman (ed.), Emergent Inequalities in Aboriginal Australia, Oceania Monograph No. 38, University of Sydney, Sydney.

Land Tribunal 1995. Aboriginal Land Claims to Vacant Crown Land in the Vicinity of Birthday Mountain, Land Tribunal, Queensland Government, Brisbane.

Martin, D. F. 1993. Autonomy and Relatedness: An Ethnography of the Wik People of Western Cape York Peninsula, PhD Thesis, ANU, Canberra.

2003. 'Rethinking the design of indigenous organisations: the need for strategic engagement', CAEPR Discussion Paper No. 248, CAEPR, ANU, Canberra.

Merlan, F. 1981. 'Land, language and social identity in Aboriginal Australia', Mankind, 13: 133-48.

1998. Caging the Rainbow: Places, Politics, and Aborigines in a North Australian Town, University of Hawaii Press, Honolulu.

2005. 'Explorations towards intercultural accounts of socio-cultural reproduction and change', in M. Hinkson and B. R. Smith (eds), Figuring the Intercultural in Aboriginal Australia, Special Issue, Oceania, 75 (3): $167-82$.

Myers, F. 1986. Pintupi Country, Pintupi Self: Sentiment, Place and Politics Among Western Desert Aborigines, University of California Press, Berkeley. 
Rigsby, B. 1999. 'Aboriginal people, spirituality and the traditional ownership of land', International Journal of Social Economics, 26 (7/8/9): 963-76.

Rowse, T. 1992. Remote Possibilities: The Aboriginal Domain and the Administrative Imagination, North Australia Research Unit, ANU, Darwin.

Rumsey, A. 1989. 'Language groups in Australian Aboriginal land claims', Anthropological Forum, 6 (1): 69-79.

Sanders, W. 2004. 'Thinking about Indigenous community governance', CAEPR Discussion Paper No. 262, CAEPR, ANU, Canberra.

Scott, J. C. 1998. Seeing Like a State: How Certain Schemes to Improve the Human Condition Have Failed, Yale University Press, New Haven.

Smith, B. R. 2000a. 'Local and diaspora connections to country and kin in Central Cape York Peninsula', Native Title Research Unit Issues Paper 2(6), Native Title Research Unit, AIATSIS, Canberra.

2000b. Between Places: Aboriginal Decentralisation, Mobility and Territoriality in the Region of Coen, Cape York Peninsula (Australia), PhD Thesis, Department of Anthropology, London School of Economics and Political Science, University of London, London.

-2004. "The social underpinnings of an "outstation movement" in Cape York Peninsula, Australia', in J. Taylor and M. Bell (eds), Population Mobility and Indigenous Peoples in Australasia and North America, Routledge, London.

2006. "More than love": locality and affects of indigeneity in Northern Queensland', The Asia Pacific Journal of Anthropology, 7 (3): 221-35.

2007. 'Towards an uncertain community? The social effects of native title in Central Cape York Peninsula', in B. R. Smith and F. Morphy (eds), The Social Effects of Native Title: Recognition, Translation and Coexistence. CAEPR Monograph No. 27, ANU E Press, Canberra..

Strathern, M. 1992. 'Parts and wholes: refiguring relationships', in A. Kuper (ed.), Conceptualizing Society, Routledge, London.

Sullivan, P. 2005. 'Searching for the intercultural, searching for the culture', in M. Hinkson and B. R. Smith (eds), Figuring the Intercultural in Aboriginal Australia, Special Issue, Oceania, 75 (3): 183-94.

Sutton, P. 1996. 'The robustness of aboriginal land tenure systems: underlying and proximate customary titles', Oceania, 67 (1): 7-29.

2003. Native Title in Australia: An Ethnographic Perspective, Cambridge University Press, Cambridge. 
Thomson, D. F. 1933. 'The hero cult, initiation and totemism on Cape York', Journal of the Royal Anthropological Institute, 63: 453-537.

Trigger, D. 1986. 'Blackfellas and whitefellas: the concepts of domain and social closure in the analysis of race relations', Mankind, 16 (2): 99-117.

1992. Whitefella Commin', Cambridge University Press, Cambridge.

von Sturmer, J. R. 1984. 'The different domains', in Australian Institute of Aboriginal Studies, Aborigines and Uranium: Consolidated Report on the Social Impact of Uranium Mining on the Aborigines of the Northern Territory, AIAS, Canberra.

Woodburn, J. 1982. 'Egalitarian societies', Man, 17 (3): 431-51. 